\title{
Diaries and Bearing Witness in the Humanitarian Field
}

Structural contexts, including the nature of social fields, affect whether and how actors engage in acknowledgment, silencing, or denying. ${ }^{1}$ In the case of the Armenian genocide, embeddedness in fields that transcend the boundaries of the Ottoman state encouraged acknowledgment. A dense trail of testimony left behind by international eyewitnesses has fed into today's body of knowledge about the Armenian genocide. Reports by consuls and ambassadors, and especially diaries by missionaries involved in humanitarian aid work in Turkey during World War I, feature prominently. In this chapter, I focus on one example from the field of humanitarianism from which I quoted at the outset of the preceding chapter: a diary written between 1915 and 1919 by Carmelite Christie, an American school administrator and humanitarian in the Turkish town of Tarsus.

In the symbolic interactionist tradition, I think of diaries as objectivationsthoughts written down and reflecting, in the words of George Herbert Mead (1934), inner conversations between the "I," that responds to a social situation, and the "Me," that part of our minds that anticipates and takes into account patterned reactions of others to our utterances. Importantly, those others are not free floating, but are themselves embedded in social fields in which they act and form a habitus (Bourdieu 1984). Introducing the terms field and habitus, I take the unusual step of linking George Herbert Mead's theory of thought with Pierre Bourdieu's field theory. Field, for Bourdieu, refers to a set of actors who pursue specific goals such as accumulating power (political field), finding truth (field of scholarship), practicing justice (judicial field), or providing aid (humanitarian field). Fields also impose particular rules of the game on participants, and they form the participants' habitus, or relatively stable dispositions (Bourdieu 1984). The stress is on "relative": habitus leaves room for improvisation, and this is where 
symbolic interactionism (with its focus on fluidity) and field theory (with its stress on structure) converge.

Workers in the humanitarian aid field are oriented toward alleviating suffering and saving lives. This mission may motivate them to depict the suffering and plead to the outside world for help. Their writings should thus constitute one of the clearest examples of acknowledgment. Yet humanitarians also act in the context of states and their enforcement apparatus, and those states may well be-as in the Ottoman context-perpetrators themselves. Such context likely inserts caution into the testimony of humanitarians, possibly as accommodation to state authorities. The history of humanitarianism is rich with examples of this tension. The failure of the International Committee of the Red Cross to ring the alarm bells after inspecting the Nazis' Terezin Concentration Camp, all for the sake of neutrality, is one of the low points of humanitarianism. Organizations such as Médecins Sans Frontières (Doctors Without Borders), formed in reaction to such constraints during the Biafran War in Nigeria, are determined to bear witness. Yet, in concrete situations, they too have to accommodate repressive political regimes, unless they are ready to pay the price of expulsion from the field (Weissman 2011). The work of Médecins Sans Frontières in-and its eviction from-the Darfur region of Sudan is but one recent example (Savelsberg 2015). In short, humanitarians desire to bear witness, but they are constrained by the perpetrating state on whose collaboration, or at least toleration, they often depend.

Diaries are a partial way out of this dilemma. Their authors write in private, not for (immediate) publication. In addition to the desire to bear witness, the writing of diaries also serves as a tool toward surviving challenging contexts. It helps their authors manage difficult, at times seemingly unbearable, situations. Anne Frank's diaries, written in her hiding place in Amsterdam, are but one famous example. A more recent case in point is Antjie Krog, who reported for the South African Broadcasting Corporation about the excruciating testimony of suffering and perpetration before the South African Truth and Reconciliation Commission. Experiencing each session and interviewing many victims and perpetrators, Krog was able to continue her work only by writing down what she heard. Her reflections resulted in a disturbing text, later published under the title Country of My Skull (Krog 1998).

The fact that authors of diaries preserve their writings-even if they do not (at least initially) seek publication-indicates that their purpose is not just therapeutic. Might some want their writings preserved as a record of the world in which they lived and suffered, as testimony of their experiences? In fact, some authors, such as Krog, or their surviving relatives, such as Anne Frank's father, do eventually publish diaries written privately under trying circumstances. While neither Carmelite Christie nor her descendants published her writings, the texts did survive and later generations decided to make them accessible as archival documents. 


\section{CARMELITE CHRISTIE AND HER DIARIES: TARSUS,}

TURKEY, 1915-1919

Sarah Carmelite Christie, née Brewer, was born in 1852 in small-town Illinois as the daughter of a minister and farmer and his housekeeper wife. She attended Rockford Seminary, from which she graduated in 1871 . She briefly worked as a schoolteacher until she married Thomas D. Christie, a Civil War veteran and Congregational missionary, in 1872 . As a child, Thomas had emigrated with his parents from Ireland to settle in Wisconsin.

In 1877 , the couple, with their first living child, moved to Turkey, where, for sixteen years, they were engaged in missionary work in the mountainous town of Marash (Maraş), about a hundred miles north of Aleppo. In 1893, two years before the Hamidian massacres of hundreds of thousands of Ottoman Armenians under Sultan Abdülhamid II, the family, now with five living children, moved to Tarsus, a town west of Adana, close to the Mediterranean coast. There, Thomas Christie assumed the presidency of the Saint Paul Institute, a privately funded college. $\mathrm{He}$ traveled much, to missionary outposts and to raise funds, the college's benefactor having died shortly after he took over the presidency, leaving the institution without adequate funding. Consequently, Carmelite was often alone in Tarsus, raising the children and working on behalf of the college, especially toward the education of women. In 1915, shortly after the beginning of the mass violence against the Armenians, Thomas traveled to Constantinople, seeking to intervene with the government on behalf of several teachers whom the authorities threatened with deportation. Not only did the government not grant his request, it did not allow him to return to Tarsus. Carmelite now had to fend for herself and for the Saint Paul Institute throughout the remainder of World War I and beyond, from 1915 until 1919. She managed to keep the institute open initially, and she worked to provide humanitarian aid to the displaced and to victims of war after its closure on November 26, 1915. In 1920, more than a year after the war ended, the couple, now reunited, returned to the United States.

\section{Data: Archives and Selection}

The following pages are based on the Thomas and Carmelite Christie and Family Papers, archived by the Minnesota Historical Society (MHS, n.d.), which contain "Correspondence, diaries, and other papers documenting the lives of a family of Protestant missionaries from Minnesota serving in the Turkish cities of Marash and Tarsus." According to the file description, "Family letters, essays, and diaries by Carmelite and Mary [a daughter] detail the sufferings of the Armenian people during the 1895,1909 , and 1915 massacres, and the missionaries' efforts to give them refuge and relief" (see note 2). Given my interest in knowledge about the genocide, I selected, from this wealth of materials, the diaries Carmelite Christie wrote between 1915 and 1919. ${ }^{3}$ In addition, I analyzed The Treatment of 
Armenians in the Ottoman Empire 1915-16, a compilation of consular and missionary reports published in a British government series.

Reading all her diaries of this five-year period, my research assistants and I documented all instances in which Carmelite Christie describes the suffering of Armenians and others affected by violence and disease, the constraints imposed by the Turkish government against intervention, and finally the compromises Christie accepted so that she would be able to continue her humanitarian work while simultaneously bearing witness to suffering and persecution. Her testimony is acknowledgment, but a conservative one in light of the threatening context in which she operated.

\section{In Her Own Words: Torn between Desire to Bear Witness and Constraint}

Carmelite Christie intensely experienced the conflict between her desire to bear witness, to document, and to acknowledge, on the one hand, and the necessity to navigate threats and demands by the Turkish state while seeking to provide aid to the suffering population on the other. Impediments in communicating to the outside world, due to censorship and control by the Turkish government, are among the constraints about which Christie reports repeatedly. For example, on October 18, 1915, she writes about a ship heading to America and her attempt to send even modest communication to the outside world: "A little gift of mine in an envelope to Agnes [a daughter] for Christmas was kept because I had written a few words on a slip of paper about it, and enclosed. Four 'officers of the Law' were present at the examination" (MHS Box 28:15). Again, on December 7, 1915, Christie mentions difficulties in communication to and from America. She describes an exceptional opportunity to do so, but expresses her general resignation: "Under ordinary circumstances it is impossible to get messages from America by cable or wireless" (MHS Box 28:37). Given such impediments against communication with the outside world, the writing of diaries was not just a therapeutic exercise for Carmelite Christie. It was also the only way to document her observations, possibly in the hope that they might one day reach the public.

The Turkish government did not merely restrict communication to the outside world. It also imposed constraints on delivery of aid to refugees from persecution and severely punished those who did not obey. On April 29, 1916, Christie writes in her diary,

We hear that the Priest is in Adana to be tried for the crime (!) of trying to hide exiles. He had none in his house: but probably knew where certain others were, and helped them. Awful threats are made against those who do anything for exiles, and the feeling against all Christians is increasing. ... It seems best to lie a little low [underlined in original] just at present. ... It would be disastrous for us to try to shelter fugitives. With so many soldiers on the premises and all about us, we could not hope to escape 
detection.... We are practically buying [underlined in original] the goodwill of those [who] might make life uncomfortable for us. (MHS Box 28:66, 67)

Carmelite Christie must have been a woman of extraordinary determination and courage. While she is reluctant to shelter refugees, her efforts to engage in relief work continue unabated, albeit with a cautious eye toward the authorities. An entry of April 9, 1917, states: "It would be hard on the poor should my hands be tied so that I could not continue relief work. I have an idea that if worse came to worst, that I might offer to superintend a Red Crescent Hospital on our premises on condition of retaining our present servants, cooks, table-boys, etc. I know nothing of such work, but might piece out guess work by self assurance and sympathy and smiles! These are times when one must use her wits for all they are worth,- and a little more" (MHS Box 28:117).

Another strategy that allows Christie to continue her humanitarian work is going under the radar of the authorities. In the same context, she thus writes in April 1917: "The govt is not in sympathy with relief work, so I do nearly everything so quietly that very few have any idea of how much I am doing. I am supposed to be simply a kind neighbor, by the Turks" (MHS Box 28:145).

Government intervention not only makes the hiding of refugees dangerous and aid provision difficult; it also infringes on the regular functions of the institute for which Christie is now responsible. On October 4, 1915, she describes the possession of school buildings by the government: "From Adana comes word that the Govt want the premises and buildings of the Girls' School (American) for a hospital. Already they have all their own school buildings, the Protestant school and church (from which they have moved the bell), the Gregorian schools and churches, and all the fine large buildings used for boarding schools by the Catholics" (MHS Box 28:7). A few weeks later, on October 25, 1915, she reports: "We ... also lose [sic] our gymnasium, eight furnished recitation rooms, and a lot of dormitory space" (MHS Box 28:19).

The decisive moment for Christie's own institution comes on November 26, 1915, when her school closes and police take over. "He [government agent] told us briefly that within 2 hours he was to have a full list of our students, place of residence, parents' names etc, and that day pupils should be separated and dealt with by themselves. Mr. Nute [Carmelite's son-in-law] asked for his authorization papers. He said they were not necessary. . . . Our good Kaimakam [Provincial Administrator] has been sent elsewhere, and his 'Vekil' [representative] is the judge who is the arch enemy of foreign institutions. It seems the order is direct from the Vali [Provincial Governor]" (MHS Box 28:30-31). Much remains in the dark in this diary entry. Why would the police want all the student information? Clearly, the intent was not friendly.

The pressure to accommodate the Turkish authorities continues throughout the following years. For example, on August 28, 1917, Christie writes about needing 
to prioritize favors to the Turks to live safely and for the sake of "the distribution on the sly of relief funds, fearing each day that you will be called to account for it. . . In my place they would understand that to some extent, to keep the peace one must in Turkey 'do as the Turks do'” (MHS Box 28:158). A few months later, on November 4, 1917, she reports that their yard is still full of Mersin prisonersSyrian Arabs, mostly-and troops coming and going, and sick soldiers brought here for convalescence. "We couldn't refuse without losing the goodwill of one whose favor may be useful to us. I have to think of the Armenians in our service" (MHS Box 28:192). Even at this late stage, it seems as though Armenians in the service of international institutions could still survive. Christie's sense of responsibility for these survivors simultaneously intensified the pressure she felt to accommodate the authorities.

In sum, Carmelite Christie, missionary and school administrator in Tarsus, Turkey, describes in her diaries of 1915 to 1919 how she initially sought to continue the functioning of her college and worked throughout to help refugees and others who sought aid. She experienced dilemmas faced generally in the field of humanitarian aid. To provide aid, humanitarians need to accommodate the authorities in order to retain access to those in need, even if the same authorities are responsible for much of the suffering the aid worker seeks to alleviate. It is under such conditions that Christie, during times of violence, observed and sought to find a balance between aid delivery and bearing witness in the form of diaries. The quotations above show that constraints posed by the Turkish state entered into Christie's "Me" (in the sense discussed above). What, then, does Christie tell us in her diaries about the violence and the suffering of the population? How does she bear witness and acknowledge these, in line with her position in the humanitarian field, but cautioned by the powerful role of state actors whose goodwill she had to secure? The following section provides exemplary observations.

\section{A Humanitarian's Local Knowledge: "We Hear of Terrible Things, and of Massacres"}

While Carmelite Christie's writings are constrained by the context in which she operates, they nevertheless provide rich testimony regarding the mass violence against the Ottoman Armenians. Christie writes about those who suffer, but also about those who perpetrate. Her pages make clear that she is not driven by resentment against Turks. In fact, she extends help to Turks, at times under pressure, to keep the authorities on her side, at other times voluntarily, especially toward the end of the war and in face of the suffering of the local Turkish population. Throughout, some themes repeat: massacres, deportations, authorizations of violence, misery of the evicted on their trek toward the deserts in the Southeast, forced conversions and the abuse of girls and young women. To convey the unfolding of events over time, I present a selection of Christie's diary entries about victimization and atrocities in chronological order. 
Available diary entries begin on October 1, 1915, five months and one week after the deportation and killing of hundreds of Armenian dignitaries and intellectuals on April 24, and continue in the following weeks of the same year. ${ }^{4}$ Christie's first entry confirms scholarship according to which killings and deportations were in full force by the fall of 1915. I quoted earlier from her entry of October 1, 1915, in which she writes about massive displacements, misery, and deaths of the suffering as well as massacres (MHS Box 28:2-3). Four Red Cross nurses ("Catholics from Germany") confirm the conditions of refugees described there: "[On their way from Constantinople to Beirut] they told of the suffering multitudes that filled the way all along the route. There were oh so many old people, lame and bent, and so many little children and so many who were ill, and they saw people dying by the roadside. The majority were on foot" (MHS Box 28:8). On November 2, 1915, Christie mentions theft of property, exiling, and massacres: "Many who worked near Tarsus during the summer, now have no homes. Their families have been exiled. Nearly all Armenians have at least lost their property. In some cases parents have been massacred” (MHS Box 28:21). Six days later, on November 8, Christie says more about massacres: "Our streets still swarm with soldiers. . . . We understand that the Arab soldiers now here came via Oorfa [Urfa]; and are the ones who massacred there. I fear there was an attempt at self defense which made matters much worse, the Armenians being always the weaker in means and numbers. It is only occasionally one hears of their giving trouble to their persecutors" (MHS Box 28:22).

At times, visitors come through Tarsus and describe what they observed on their travels. For example, on November 13, 1915, Christie writes: "Miss Ditson of Hadjin came yesterday and went on today. She told us of the burning of Hadjin, that of about 3000 houses, only 300 remained, and those are the very poorest, and a few Moslem houses. . . . It is an open secret that the city was destroyed by an order of the Govt. under special superintendance" (MHS Box 28:23).

Christie's observation regarding the "open secret" is significant. What the sultan did publicly, the Young Turks executed primarily through their Special Organization, with an attempt to leave no traces, no proof, as little documentation as possible. Yet officials were told of these actions informally, and people knew because they witnessed the violence.

Displacement accompanied the destruction of Armenian settlements, and so the observations on the following page are not surprising: "Awful accounts come to us from those in camp at Külek [Gülek] Station" . . . One of our church men assists in the soldiers' hospital at Külek Station, and so sees the people camping about. He tells of a family of 12 who were gathering grass and roots and boiling them for food.... We hear of terrible things, and of massacres" (MHS Box 28:24).

Book 2 of the diaries starts the way Book 1 ended. On November 17, 1915, Christie reports: "People are not allowed to remain long at Külek Station where they are actually dying from hunger. Our agents are giving secretly food and money to 
as many as possible, since money has come by telegram 'on John's account.' I keep women at work making coarse underclothes and warm petticoats for some of the poorest who were robbed en route, and are penniless and without change og [sic] garments" (MHS Box 28:25).

The remaining diary entries of 1915 similarly report mass violence. On December 18, an acquaintance "tells of auful [sic] conditions in Osmania, and says the treatment given Armenian children can't be told, and that numbers of such children were carried off by the Turks to be made Moslems" (MHS Box 28:41). Later: "Several old and feeble-near dead people, were buried with five corpses in a common pit! One woman, still alive, pushed her hand through the earth and waved it to call attention. Later the dogs came and ate the hand! This horrible incident called forth a remonstrance even from the cowed Armenians, and the Pasha receiving it, forbade a repetition of this inhuman treatment of human beings" (MHS Box 28:41-42). A subsequent entry includes reports of massacres in Urfa, Armenian attempts at resistance that were crushed, "and then followed a most horrible butchery with knives and bayonets and guns etc., the Moslem women following and sometimes smashing in skulls with stones!” (MHS Box 28:45). Again, massacres are accompanied by the taking of property. On December 20, 1915, Christie writes about the government's “open robbery in seizing Armenians' property-houses and lands and even the bales of rugs and bedding and bureaus etc." (MHS Box 28:42).

In short, Christie's diary entries of late 1915 speak to atrocities committed by the Turkish military, the Special Organization, and at times civilians against the Armenian population. Mass killings, arson, deportation, and robbery are part of the unfolding events.

Descriptions of victimization and suffering are less frequent in the diary entries of 1916. Yet what we read speaks to the continuation of mass evictions and killings begun in the preceding year. For example, on April 6, travelers report of recent massacres: “They saw awful sights, and tell awful tales" (MHS Box 28:62). On April 17, Christie writes about impediments to aid: "Our sewing has been taken from us. The Govt do [sic] not wish the Armenians to receive favors from foreigners. They promised to give our women work from their depot, and we have sent their names, each carrying our card. Thus far excuses have been made and no work given to those we sent. Others (Turkish and Arab women) got enough" (MHS Box 28:64).

On the evening of the following day, the news is of deaths of those close to Christie: "This time it is one of our old pupils, Gülabi Kouyoumjian, also Eyilmezian and son, and Suren Azirian. Scarcely a day passes in which we do not hear of the death of some Tarsus exile" (MHS Box 28:69).

Entries of 1917 suggest that the government is working to eliminate remnants of Armenian life. On January 30, Christie's bewilderment about massacres of civilians continues, as she writes that "one cannot,-simply cannot [underlined in 
original] understand the cruelty of Turks in treatment of the families of Christians. How can they instigate massacres! Have they no fellow feelings? It's a mystery to me" (MHS Box 28:107).

A March 6, 1917, entry describes again the fate of children:

Last evening an eye witness who was at the RR [railroad] station when the train came in, saw over two hundred little Armenian orphans taken from five cars and driven by an officer into the garden across the road, and later on up in to the city: They were from four or five years old up to perhaps fourteen, and the majority were boys.... They appeared like children who had been under supervision, and were in a uniform dress that suggested the Germans. We have a fear that they may have been taken from the German orphanage in Aleppo which was in charge of Miss Rhoner. We have had vague reports of designs against her work. (MHS Box 28:112)

On August 23, 1917, attention shifts to the Greek population while Armenian survivors are crowded into Aleppo: "The Greek subjects [emphasis in original] are doomed to exile, and the Mersine Greeks are now in Tarsus awaiting orders. . . . Aleppo is full to overflowing with Armenian exiles" (MHS Box 28:155). Christie describes local conditions as worsening further. ${ }^{6}$

By early 1918, the defeat of Turkey and the other Axis powers becomes increasingly predictable. The character of Christie's diary entries changes accordingly. Signs of hope and new beginning mix with reports of new atrocities and continuing suffering. On January 19, Christie writes about plans to reopen the school, making it self-supporting. She writes about Muslims asking for such a school. "There will be Greeks and Armenians also-all boys" (MHS Box 28:206).

Some of the exiles manage to return to their places of origin, as an entry of March 27, 1918, indicates: "It's wonderful how people in Exile manage to get back one by one into the region of their former home. Yesterday a Hadjin woman came from Mosul! .. . Her family ... were massacred some time ago. She was nearly naked and the boy had only a few tatters of one garment clinging about him. They were hungry and penniless. We gave them money and underclothing, and must see about giving them a lodging place" (MHS Box 28:220).

A diary entry of April 10 again reflects hope, but also struggles with the Turkish authorities over the continuation of the extermination campaign:

People are hearing from Marash, and one person has come from there. There was a time of anxiety and a few were exiled, I believe, but no massacre [underlined in original]. The same was true of Adana. Here there was much uneasiness for a few days, as recorded before. It seems that a certain party wanted the Armenians to be sent away, but as no region or city wanted more exiles, there was an intention to dispose of them en route. Orders came, however, from those high in authority in Constantinople that the Armenians were not to be disturbed, save perhaps a few troublers of the peace who were to be exiled. Friday April 5th was the day when something was to have occurred that would have reduced the population, but God turned the hearts of those in influence so that we went to our beds at the close of the day, and slept and 
awoke in safety. So it is that God keeps us amidst alarms. Of many dangers we are unconscious. (MHS Box 28:224)

Despite signs of hope, danger and fear continue. On April 4, Christie writes that "still, deportations and massacres come suddenly, so I am not surprised at the frequent apprehensions of the people" (MHS Box 28:223). She sees signs that also the last remnants of minority populations will be destroyed.

On August 12, just three months before the end of the war, notes indicate a mixture of hope and resignation: "There is a report that the new Sultan [Mehmed VI, as of July 4, 1918] has forgiven the exiled Armenians, and that they are free to return to their homes. This is good policy on his part, but what of all the property he confiscated, houses torn down, goods sold, gold appropriated, and all the death and suffering that have come upon a helpless people?" (MHS Box 28:244). ${ }^{7}$

With the end of the war in November 1918, the horrendous state of survivors becomes a central topic of Christie's remaining diary entries. On a trip to Adana, she reports, she

went over to the American Girls' Seminary where about 900 returned exiles are staying. There are many more in other centers in Adana. Such a crowd! All of them dirty, unkempt and spiritless men and women and children. The men were in minority. There were many young women who had been captives among the Koords [Kurds]. Some had already given birth to children. Others were soon to be confined. The photographer of the expedition took several photos. One was of a group of young women who had hands and faces disfigured. . . Helpers are to come to us after a while to open orphanages and help in other ways with relief work. (MHS Box 28:289) ${ }^{8}$

Carmelite Christie, a missionary, school administrator, and teacher in Tarsus, writing between 1915 and 1919, thus describes the suffering she observes and about which she learns from travelers and close acquaintances. The expulsions and massacres to which the Armenian population was exposed stand out in her reports.

Several observations are in order from a sociology of knowledge perspective. First, Christie's diary entries are reflections of an inner conversation, including her spontaneous reactions to the violence she observes or about which she learns from eyewitnesses. Second, her "Me" - again, defined as that part of the self that takes into account the imagined other, especially, in her case, the potential reactions of the Turkish state-reflects the habitus of a humanitarian aid worker whose ability to function depends on cooperation by the regime that bears responsibility for the suffering. Because bearing witness under such circumstances is challenging, we have to take Christie's descriptions even more seriously. Third, Christie writes her observations from a local perspective. They are direct, fresh, documented in real time. Yet they only partially reflect the bigger picture. Even information she obtained from others mostly speaks to the part of Turkey in which she resided. Fourth, and finally, Christie's observations became part of the historical record, one puzzle piece among many, contributing to a body of knowledge about mass 
violence against the Armenians. Her observations alone would certainly not have shaped knowledge in subsequent decades. Yet many other witness testimonies, even if varying by geographic region, overwhelmingly confirm the overall pattern of genocidal violence.

\section{FROM A SINGLE VANTAGE POINT TO A PATTERN OF OBSERVATIONS: THE BRITISH BLUE BOOK}

Christie's observations report about a region of the Ottoman Empire where Armenians were relatively wealthy and concentrated in cities. In such places, in conditions that did not apply everywhere, Armenians provided a convenient (and profitable) target. Historical research consequently shows geographic variation in patterns of violence (Kezer 2019), patterns to which the cover picture of this book speaks. French photographer Josephe Marando took that picture in the town of Sölöz, near the city of Bursa, south of Istanbul. The Armenian population was evicted from Sölöz in 1915. Some were saved from deportation into the Syrian Desert by Djelal Bey, governor of Konya, and returned home at the end of the war in 1918.9 These Armenians were displaced again in 1922, after the War of Independence. Sölöz was taken over by Muslims, originally from Bosnia and Bulgaria, resettled in 1923 to Asia Minor from the region of Thessaloniki and Drama (today Greece). This latter resettlement was part of a massive population exchange approved by the victors of World War $\mathrm{I}^{10}$

Despite such variation, hundreds of pieces of documentation, penned by consuls and other missionaries from all over Turkey during the years of World War I, parallel Carmelite Christie's diary entries. While the intensity of violence varied, the many observations accumulate to a Gestalt that reveals the genocidal nature of the aggression committed against the Ottoman Armenians.

Numerous reports are assembled in The Treatment of Armenians in the Ottoman Empire 1915-16, a book written by British historian and diplomat James Bryce in collaboration with historian Arnold J. Toynbee (Bryce and Toynbee [1916] 2005]). The volume allows us to place the small tile provided by Carmelite Christie into the larger mosaic that emerges from accounts by many observers across the Ottoman Empire. Composed primarily of documentation, supplemented by discussion and analysis, the book appeared in 1916 in the British Parliamentary Blue Book series in the form of a legal report (in the following, I will refer to it simply as the Blue Book). Nearly all of the evidence came from primary sources. Authors of these sources agree that "starting in the spring of 1915, the Ottoman government had embarked on a systematic program to annihilate Armenians in the Ottoman Empire" (Bryce and Toynbee [1916] 2005:vii).

Analyzing the Blue Book, my research assistants and I coded a total of 150 general descriptions or accounts provided by eyewitnesses. Similar to our analysis of the Christie diaries, we focused on reports about bearing witness, providing relief support, conflict between these two goals, and compromises. 


\section{Information Constraints and Background of British Information Politics}

In a background section included in its "Introduction," the Blue Book speaks to information control practiced by the Ottoman Empire and its German allies. Both "Constantinople and Berlin exercised a strict regime of censorship and misinformation regarding the fate of Armenians" (Bryce and Toynbee [1916] 2005:viii). This depiction is in line with Christie's local observations from Tarsus. The British government initially hesitated to publicize information about the fate of the Armenians. It feared detrimental effects that revelations about the mistreatment of Christians in Turkey could have on its relationship with allied Muslim leaders. Yet "the turning point in the British position came after October 4th 1915, when the United States government began releasing information on the destruction of Ottoman Armenians. This was through a front organisation called the Committee on Armenian Atrocities (CAA), which had direct access to State Department files from Ottoman Turkey" (Bryce and Toynbee [1916] 2005:viii).

Indeed, it appears as though most of the information about the fate of the Armenians was communicated to British authorities from the Ottoman Empire via the United States. A central actor in this transmission was Reverend James Barton, head of the American Board of Commissioners for Foreign Missions, the Committee on Armenian Atrocities, and the American Committee for Armenian and Syrian Relief. Barton, the Blue Book informs us, "was highly respected in President Wilson's administration, [and] had direct access to American consular reports from the interior of the Ottoman Empire" (Bryce and Toynbee [1916] 2005:xiii). Such reporting, collaboration with humanitarian aid organizations, and the channeling of relief funds were possible because the United States was still a neutral power in 1915. In addition, prior to the war, American missionaries had enjoyed excellent relations with the American Department of State (see Sarafian 1994, 2004; Morgenthau 2003).

Yet caution was the order of the day. "In one communication to Bryce, Barton explained, 'Our State Department allows me to make public use of the material if I can conceal the source of information. The Consuls in Turkey have been warned [by the Turkish authorities] against reporting the local conditions. There is a danger that if publicity matter can be traced to the Consuls they may be sent out of the country"” (Bryce and Toynbee [1916] 2005:xiii). Such concerns about disruptions of diplomatic ties have consequences similar to those feared by humanitarian aid workers. Here, as in other cases, they suggest caution in reporting about atrocities (Savelsberg 2015: chapters 6 and 7). Much in line with Christie's specific situation, what aid workers and diplomats report, despite the risks of bearing witness, should be taken all the more seriously. It likely constitutes a conservative assessment of repression and atrocities.

\section{Atrocities Reported in the Blue Book}

Segments of the Blue Book speak to the treatment of the Armenian population in the Ottoman Empire in the years 1915 and 1916. The content of these reports from 
various locales is similar to what we learn from the diaries of Carmelite Christie. While Christie describes massacres, evictions, neglect, and abuse of women primarily from her local perspective, this volume suggests patterns across the empire. A few examples have to suffice in this context. ${ }^{11}$ The first is an excerpt from a letter "from an authoritative source," dated August 15, 1915, addressed to an Armenian outside of the empire:

It is now established that there is not an Armenian left in the provinces of Erzeroum [Erzerum], Trebizond, Sivas, Harpout [Harput], Bitlis and Diyarbekir. About a million of the Armenian inhabitants of these provinces have been deported from their homes and sent southwards into exile. These deportations have been carried out very systematically by the local authorities since the beginning of April last [1915]. First of all, in every village and every town, the population was disarmed by the gendarmerie, and by criminals released for this purpose from prison. On the pretext of disarming the Armenians, these criminals committed assassinations and inflicted hideous tortures. Next, they imprisoned the Armenians en masse, on the pretext that they had found in their possession arms, books, a political organisation, and so on-at a pinch, wealth or any kind of social standing was pretext enough. After that, they began the deportation. And first, on the pretext of sending them into exile, they evicted such men as had not been imprisoned, or such as had been set at liberty through lack of any charge against them; then they massacred them-not one of these escaped slaughter. Before they started, they were examined officially by the authorities, and any money or valuables in their possession were confiscated. They were usually shackled-either separately, or in gangs of five to ten. The remainder-old men, women and children-were treated as waifs in the province of Harpout [Harput], and placed at the disposal of the Moslem population. The highest official, as well as the most simple peasant, chose out the woman or girl who caught his fancy, and took her to wife, converting her by force to Islam. As for the children, the Moslems took as many of them as they wanted, and then the remnant of the Armenians were marched away, famished and destitute of provisions, to fall victims to hunger, unless that were anticipated by the savagery of the brigand-bands. In the province of Diyarbekir there was an outright massacre, especially at Mardin, and the population was subjected to all the afore-mentioned atrocities. In the provinces of Erzeroum [Erzerum], Bitlis, Sivas, and Diyarbekir, the local authorities gave certain facilities to the Armenians condemned to deportation: five to ten days' grace, authorisation to effect a partial sale of their goods, and permission to hire a cart, in case of some families. But after the first few days of their journey, the carters abandoned them on the road and returned home. These convoys were waylaid the day after the start or sometimes several days after, by bands of brigands or by Moslem peasants who spoiled them of all they had. The brigands fraternised with the gendarmes and slaughtered the few grown men or youths who were included in the convoys. They carried off the women, girls and children, leaving only the old women, who were driven along by the gendarmes under blows of the lash and died of hunger by the roadside. An eye-witness reports to us that the women deported from the province of Erzeroum [Erzerum] were abandoned, some days ago, on the plain of Harpout [Harput], where they have all died of hunger (50 or 60 a day). (Bryce and Toynbee [1916] 2005:52) 
This report indeed is a strong form of acknowledgment. There is no silencing or denial, and the core message resembles that from Carmelite Christie's diaries. The fact that it was written from a distance, in a Christian nation at war with the predominantly Muslim Ottoman Empire and no alien to Orientalism, certainly favored such depiction, but it does not take away from the ontology of the violent excesses. Importantly in our context, it contributes to today's body of knowledge about the Armenian genocide.

Some reports detail conditions in specific places, for example, the following passages we identified in the Blue Book from a "CABLEGRAM, DATED 4th MAY, 1916, TRANSMITTED THROUGH THE STATE DEPARTMENT AT WASHINGTON TO THE AMERICAN COMMITTEE FOR ARMENIAN AND SYRIAN RELIEF, FROM THE COMMITTEE'S REPRESENTATIVES IN TURKEY" [caps and italics in original]. This account highlights the need for relief support in different areas based on the conditions and violent acts committed by the Ottoman government.

\begin{abstract}
Aleppo.
Relief work here supports 1,350 orphans who are only a portion of the destitute children now in the city. It has also furnished food to families in nine destitute centres, including Hama, Rakka, Killis and Damascus. $£ 1,500$ (Turkish) monthly are being used at Aleppo for orphans; $£ 600$ (Turkish) are being used for the poor of Aleppo; $£ 2,245$ (Turkish) are being used in the destitute centres. This is considered to be a minimum allocation, and ten times the amount would not meet the full needs. The work is being overseen by the German and American Consuls. So insufficient are the funds that many exiles in the destitute places have only grass to eat, and they are dying of starvation by hundreds. $£ 1,000$ (Turkish) are required each week for the Aleppo centre. $[\ldots]$
\end{abstract}

\title{
Aintab.
}

Forty-five hundred Armenians remain here, two thirds of whom are on relief lists. Four hundred refugee women and children in city and neighborhood require $£ 1,000$ (Turkish) each month.

\section{$[\ldots]$}

Tarsus.

This being a station on the route taken by the exiles from the region north of Tarsus, the roads are always full of people in miserable condition. According to Government estimates, 92,000 exiles have passed through Tarsus, while according to other reports, the number is much larger. Typhus is very prevalent. The needs here require $£ 500$ (Turkish) a month. (Bryce and Toynbee [1916] 2005:70)

With this last entry, the circle closes. The Blue Book takes us to Tarsus, that town close to the Mediterranean coast, where Christie wrote her diaries. We link back from the big picture to the descriptions of perpetration and human suffering Christie provided from a local perspective, but in great detail and enriched by depictions of the fate of specific individuals. Importantly, the Blue Book was 
compiled by prominent scholars for publication in a British government series. More than the testimony of a lone humanitarian-missionary such as Christie, it is thus backed by influential knowledge entrepreneurs. It is a powerful contributor to collective memory, backed up by a most influential institution, about the genocide against the Armenians.

\section{Excursus: A Question of Validity}

The sociology of knowledge is not concerned with the validity of knowledge, the construction and shape of which it seeks to explore. The reader might nonetheless be interested, and so here I briefly switch gears to summarize debates over the validity of the information provided by the Blue Book. While not an exercise in sociology of knowledge themselves, these debates are part of the massive epistemic struggle with which this book is concerned. They are thus subject to the sociology of knowledge.

Britain was party to the unfolding of World War I, and, generally, caution is advisable when reading war-related information issued by one party against an enemy. Consequently, critiques abound-and, in a newer introduction to the Blue Book, the editors see reason to respond:

[I]n recent years a number of partisan authors have argued that the Bryce-Toynbee volume was part of a British wartime misinformation campaign against the Ottoman Empire and its allies. Such authors have insisted that the work was based on forged documents with no scholarly merit. Enver Ziya Karal, a former dean of history at Ankara University, dismissed the report as merely "one-sided British propaganda," which was "not worth dwelling upon." Ismet Binark, former general director of the State Archives in Turkey, claimed that "the events described in the reports presented as the records of the so-called Armenian massacre ... [were] all falsified information taken from the English's files relating to the East." The Treatment of Armenians in the Ottoman Empire was "ornamented with massacre stories, unrelated with the truth, biased, written with Armenian fanaticism, and misleading the world's public opinion." (Bryce and Toynbee [1916] 2005:x)

Yet the core messages of the Blue Book are consistent with independent local reports such as those by Carmelite Christie. Many others, like hers, are buried in archives in Armenia, the United States, France, Denmark, Sweden, and Germany's foreign ministry, home of the archives of Imperial Germany. Contained in all of these archives are multiple eyewitness accounts. They include, from the world of American diplomacy, reports by Ambassador Henry Morgenthau, Consul Leslie A. Davis (in Harput), and Consul Oscar Heizer. Note that, when most of these reports were written (1915-16), the United States was not yet involved in the war. Still more significant, in light of Turkish critique of the propagandistic intent of the British Blue Book, is testimony from German sources. They include statements by Paul Graf Wolff Metternich, German ambassador in Constantinople; Walter Rössler, German consul in Aleppo; and Wilhelm Litten, head of the German Consulate in Täbris. 


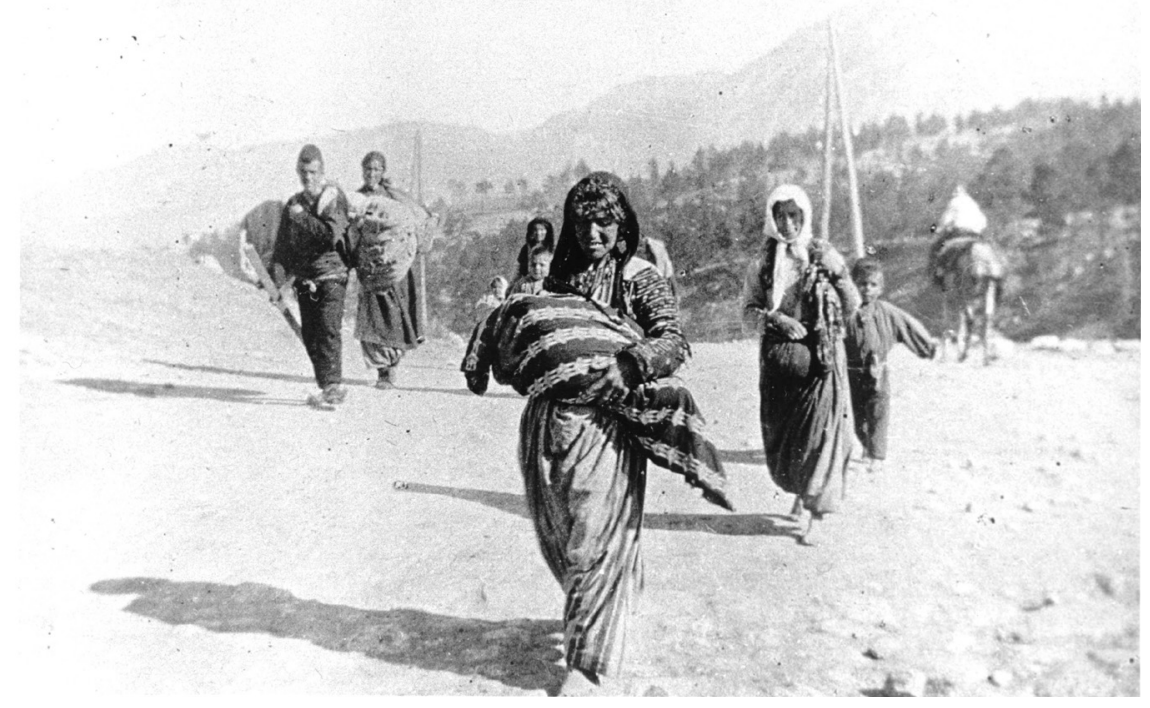

FIGURE 2. Iconic photograph by Armin T. Wegner, a German medic, depicting displaced Armenians on their trek into the Syrian Desert. Image courtesy of the Armenian National Institute, Inc. / Sybil Stevens (daughter of Armin T. Wegner). Wegner Collection, Deutsches Literaturarchiv, Marbach \& United States Holocaust Memorial Museum.

Similar reports come from the German allied military. They include testimony by General Friedrich Kress von Kressenstein of the First German-Turkish Expedition Corps; and by Armin T. Wegner, a German medical orderly, to whom we owe much of the iconic photographic evidence of Armenian suffering. Diplomatic and military testimony is supported by journalistic reports, including those by Samuel S. McClure, an American correspondent, and Harry Stürmer, German correspondent for the Kölnische Zeitung.

Christie's diary entries about the treatment of the Armenians and the documentation in the Blue Book also find manifold confirmation among humanitarians of the time. Examples are reports by Alma Johannsson and Beatrice Rohner, missionaries from Sweden and Switzerland, respectively; Tacy Atkinson, an American missionary stationed in Harput; Johannes Lepsius, head of the Armenisches Hilfswerk (German Armenian aid organization); Jakob Künzler, a German missionary and physician's aid stationed in Urfa; Martin Niepage, a teacher at a German school; Ernst Christoffel, director of a home for the blind in Sivas; and Karen Jeppe, Danish head of orphanages in Urfa and Aleppo. ${ }^{12}$

Such eyewitness testimonies, supplemented with occasional moments of acknowledgment by Turkish memoir writers (identified by Fatma Müge Göçek; see chapters 1 and 5), with photographic evidence (see figure 2), and with conclusions 
drawn by an overwhelming number of historians, suggest the validity of information that has today become sedimented in a widely accepted genocide discourse. ${ }^{13}$ Such evidence, in combination with the state of scholarship, suggests to me that I should use the term genocide against the Armenians throughout this book. Leaving this excursus on the validity of the Blue Book and the Christie diaries behind, I now return to the role of a sociologist of knowledge.

\section{CONCLUSIONS}

Social interactions result in knowledge, including knowledge about mass violence. In addition, actors engage in inner conversations and, at times, externalize and objectify such conversations, for example through the writing of reports and diaries. In disorienting contexts, including those of mass violence, they may do so because sense-making becomes a precondition of sanity, the ability to act, and possibly survival. Carmelite Christie's diaries are a powerful example. They provide testimony, even in the context of a humanitarian field, in which Christie has to be mindful of the power of government and military. In the terms we have established, the "I" (spontaneous thoughts and reactions in the face of suffering) is constrained by the "Me" (that part of the self that takes imagined reactions by others into account and that, in the social field of humanitarian aid, codetermines the habitus of the writer). The Blue Book and a multitude of archival sources show that Christie's local observations about the treatment of the Armenians were part of a broad pattern, despite some variation across the Ottoman Empire. The fact that institutions such as the British Parliament backed these observations provides them with particular epistemic power.

Finally, social interactions as well as inner reflections, externalized in the form of diaries, have cultural consequences. Knowledge generated at the microsociological level may become institutionalized, objectified, and sedimented, especially when aggregated by macro-level actors such as the authors of the Blue Book. The outcome of millions of everyday practices, thus supported, is a collective repertoire of knowledge (Berger and Luckmann 1966). It becomes the property of carrier groups (Weber 1978) - that is, collectivities defined by criteria such as religion or nationality that secure the transgenerational transmission of beliefs and worldviews. ${ }^{14}$

Importantly, not all participants in these processes are equal. Powerful entrepreneurs of memory and knowledge, with access to vast resources and channels of communication, have an outsized impact on processes of sedimentation and aggregation. State actors feature prominently among them. The next chapters explore these themes. Chapter 3 provides theoretical and conceptual tools, which help analyze, in chapters 4 and 5, how distinct, in fact radically opposed, knowledge repertoires about the mass violence against the Ottoman Armenians became the property of collectivities, specifically Armenians and Turks. 